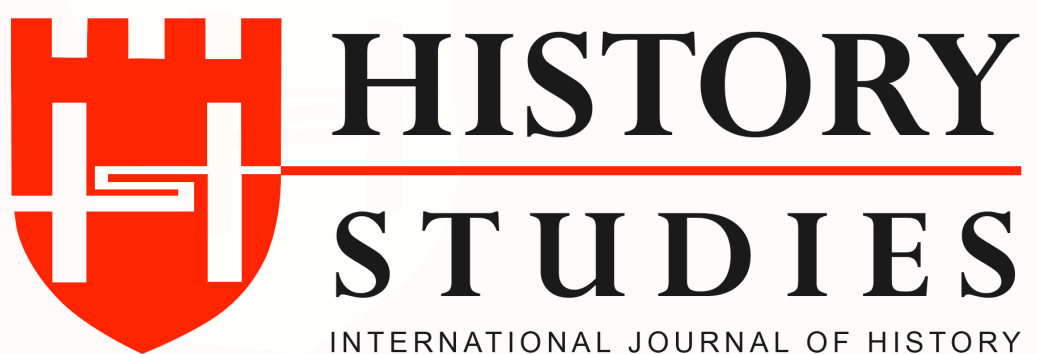

\author{
ISSN: 13094173 (Online) 1309 - 4688 (Print) \\ Volume 11 Issue 5, October 2019 \\ DOI Number: 10.9737/hist.2019.775 \\ Araştırma Makalesi
}

Makalenin Geliş Tarihi: 06.08.2019 Kabul Tarihi: 24.09.2019

Atıf Künyesi: Melih Duman, “1965 Pakistan - Hindistan Savaşı Ekseninde Keşmir Olayları ve

Türkiye'nin Dış Politikası”, History Studies, 11/5, Ekim 2019, s. 1509-1523.

\title{
1965 Pakistan - Hindistan Savaşı Ekseninde Keşmir Olayları ve Türkiye'nin Dış Politikası
}

Kashmir Events and Turkey's Foreign Policy in Axis of the 1965 Pakistan - India War

\author{
Dr. Melih Duman \\ ORCID No: 0000-0001-6861-615X \\ Aksaray Üniversitesi
}

\begin{abstract}
Özet
$\mathrm{Bu}$ çalışma 1947 yılında Hindistan ve Pakistan'ın İngiltere'den bağımsızlıklarını kazanması sonrasında Keşmir konusunda yaşadıkları anlaşmazlıkları, 1965 Hindistan-Pakistan Savaşı ve Türkiye'nin dış politikası açısından değerlendirmeye çalışmaktadır. Türkiye'nin bu dönemde, dış politikası açısından Pakistan ve Keşmir meselesini, 1965 Savaşı ve öncesinde tarihsel TürkiyePakistan dostluğu ve Türkiye'nin dâhil olduğu NATO'nun çıkarları doğrultusunda değerlendirdiği görülmüştür. Türkiye'de kamuoyu ve siyasiler için Pakistan ve Keşmir oldukça önemli bir konu olmakla birlikte, Türkiye'nin Keşmir meselesine bakıșı, bloklar arasındaki mücadele ile bağlantılı bir surette ilerlemiştir. Bu çalışma, NATO'nun Asya'da yaşadığı güvenlik endişesi ile kamuoyundan kaynaklanan politikası çerçevesinde Türkiye'nin Keşmir meselesindeki farklı bakışını ortaya koymaya çalışmakta ve 1960'lı yıllar içerisinde Türk dış politikasını ele almaktadır.
\end{abstract}

Anahtar Kelimler: Keşmir, Türkiye, Pakistan, Hindistan

\begin{abstract}
This study aims to evaluate the disputes which India and Pakistan have witnessed upon gaining independence from the United Kingdom in 1947, with regards to the 1965 India - Pakistan war and Turkey's foreign policy. It is concluded that Turkey has regarded the Pakistan and Kashmir issue in line with the 1965 war, the historic Turkey - Pakistan friendship, and the interests of NATO, of which it is a member. Although Pakistan and Kashmir were quite important topics for the public opinion and politicians, the stance of Turkey, a side of the Cold War, on the Kashmir issue, has advanced in connection with the struggle between the blocs. In this regard, the study aims to portray Turkey's different point of view on the Kashmir issue within the frame of politics stemming from security concerns which NATO has faced in Asia, and discusses the judgement of Turkey's foreign policy in the 1960 's.
\end{abstract}

Keywords: Kashmir, Turkey, Pakistan, India

\section{Giriş}

Hindistan ve Pakistan'ın 1947 yılında bağımsızlığını kazanması sonrasında, İngiltere'nin geleceğini kendi kararlarına bıraktığı 562 racalık/prenslik içerisinde yer alan Cammu-Keşmir, Pakistan'la yaptığı anlaşmayı hiçe sayarak hukuki olmayan süreç içerisinde Hindistan'ın yönetimine katılmıştır. Keşmir'in Hindistan'a katılmasını takip eden süreç içerisinde ise Hindistan, Keşmirlilerin haklarını özellikle plebisit hakkını, Birleşmiş Milletlere (BM) rağmen 
uygulamayarak üçte ikisi Müslüman olan Keşmirlileri yok saymıştır. Hindistan'ın Keşmirlilerin hakkını yok sayması ve Hint yönetiminin meşru bir otorite sağlamak üzere giriştiği şiddet ve baskı eylemeleri, Keşmirli Müslümanları ve Pakistan'1 Hindistan'la mücadeleye sevk etmiştir. Hindistan-Pakistan arasında kısa süre içerisinde çıkan savaş, 1949 yılında BM gözetiminde ateşkesle sonuçlansa da Keşmir meselesinin çözülememesi, çatışmanın sonraki yıllarda sürmesine neden olmuştur. Hindistan'ın Keşmir'deki uygulamaları nedeniyle 1960'lı yıllarda tekrar başlayan çatışmalar, 1965 yılında Hindistan ve Pakistan arasında ikinci kez savaşa dönüşmüştür.

Türkiye'nin Keşmir konusundaki dış politikası ise ikinci Hindistan-Pakistan Savaşı sürecinde değişmiştir. 1947 y1lında Hindistan'da sömürge yönetimini sona erdikten hemen sonra iki devlet arasında Keşmir meselesi konusunda yaşanılan olaylarda Türkiye'nin yeterince aktif bir dış politika takip edemediği görülmüştür. Türkiye'nin II. Dünya Savaşı sonrasında Sovyet Sosyalist Cumhuriyetler Birliği (SSCB) karşısında yaşadığı güvenlik endişesi, dış politikanın Türkiye sınırları dışına çıkmasına müsaade etmezken, 1960'lı yıllarda uluslararası ilişkilerde yaşanan detant/yumuşama dönemi, Türkiye'nin Keşmir meselesi ile ilgilenmesine imkân tanımıştır. Türkiye'nin Keşmir konusunda bu dönem içerisinde iki görüşe sahip olduğu görülmüsştür. İlk olarak Türkiye, tarihsel dostluk bağıyla bağlı olduğu Pakistan'ın her koşulda yanında yer almak istemiş̧tir. İkinci olarak ise Türkiye, dâhil olduğu NATO ittifakının bir üyesi olarak Keşmir meselesinde, ABD’nin görüşüne yakın bir faaliyet içerisine girmek durumunda kalmıştır.

1960’l1 yıllarla başlayan ve 1965 yılında savaşa dönüşen Keşmir Meselesi, Türkiye'nin dış politikasında II. Dünya Savaşı'nın sona ermesinden itibaren yaşanan kırılmanın ilk örneklerinden birisini göstermektedir. Türkiye'nin Soğuk Savaş sürecinde SSCB'ye karşı dâhil olduğu Batı kampından ilk defa 'yumuşama' döneminin etkisiyle bağımsız bir politika yürütmeye çalışmıştır. 1945 yılından itibaren SSCB tehdidi karşısında ciddi bir güvenlik endişesi yaşayan Türkiye, 1960'lı yıllara geldiğimizde uluslararası ilişkilerde yaşanan gelişmelere bağlı olarak ABD ile Kıbrıs konusunda yaşadığı problemlere bağlantılı olarak bu dönem itibariyle bağımsız bir dış politika süreci takip etmek istemiştir. Kıbrıs meselesi, SSCB endişesi, Türkiye-Pakistan tarihi dostluk ilişkileri, Türkiye-ABD ilişkilerinde yaşanan kriz 1960’lı yılların ikinci yarısı itibariyle Türkiye'nin Keşmir Meselesi ile ilgilenmesini sağlamıştır.

Türkiye ile Pakistan arasındaki dostluk ilişkisine rağmen, tarihsel süreç içerisinde Türkiye'nin Pakistan'ın Keşmir tezine çok fazla katkı sağlayamadığı görülmüştür. 1965 Savaşı sonrasındaki süreçte Ortadoğu, Kafkasya ve Balkanlar ekseninde gelişen, ortaya çıkan sorunlar Türkiye'nin Keşmir meselesine yeterince odaklanmasını engellerken Türkiye, Pakistan'ın etkisiyle konuya tamamen kayıtsız da kalamamıştır. Bu durum Türkiye'nin yalnızca kriz anlarında Keşmir'le ilgilenmesine neden olmuştur. Keşmir sorununun uluslararası ilişkiler ağı içerisindeki mevcut dinamizmi literatürde, ele alınan oldukça önemli bir konu olmasını sağlamaktadır. Bununla birlikte, Keşmir'in Türk dış politikası açısından mezkûr nedenler sebebiyle yeterince ele alınmadığı görülmüştür. Türkiye'nin Keşmir meselesine yeterince eğilememesi, beraberinde Türk dış politikasında Keşmir meselesinin değerlendirmesini de akim bırakmıştır. $\mathrm{Bu}$ eksende çalışmamız detant döneminde yaşanan değişimin etkisiyle Keşmir meselesini ele almakta ve Türkiye'nin Keşmir'e bakışını spesifik bir konu olarak değerlendirmektedir. Konuyla ilgili olarak Cumhuriyet Arşivi'nden elde edilen belgeler, oldukça önemli verilere sağlayarak Türk dış politikası açısından 1965 yılı ve öncesinde Türkiye'nin Keşmir meselesine nasıl baktığını ortaya koymamızı sağlamıştır. 


\section{Keşmir Meselesi}

Arapça kaynaklarda Keşmîr ve Kaşmîr şeklinde geçen Keşmir, Sanskrit kökenli bir isimdir. Tarih boyunca bölgeyi ziyaret eden seyyahlar bölge ile ilgili farklı isimlendirmelerde bulunmakla birlikte, yerel halk bölgeye Keşîr demektedir. Keşmir bölgesi Himalayalar'ın kuzeybatı kesiminde bulunan, $135 \mathrm{~km}$ uzunluğa ve $32-40 \mathrm{~km}$ genişliğinde verimli bir vadinin adı iken zaman içerisinde $222.236 \mathrm{~km}^{2}$ yüzölçümlü bir bölgeye verilen isim halini almıştır. Bölgenin $78.114 \mathrm{~km}^{2}$ 'si Pakistan'ın elinde bulunmaktadır. Bunun $11.639 \mathrm{~km}^{2}$ 'lik bölümü Âzad Keşmir eyaletini teşkil eder. Bölgenin Hindistan'a ait bölümü ise $101.307 \mathrm{~km}^{2}{ }^{\prime}$ lik CammûKeşmir eyaletini meydana getirir. Âzad Keşmir'in merkezi Muzafferâbâd, Cammû-Keşmir'in merkezi ise Srinagar'dır. ${ }^{1}$

Keşmir'de Müslüman yoğunlaşması XIII ve XIV. yüzyıllardaki göç, iskân ve ihtidalar ile sağlanmıştır. Keşmir'de Müslüman nüfusun artmasıyla birlikte İslamiyet'te bölgeye yerleşmiştir. Bölge Müslüman, Sih, Hindu (İngiltere'nin desteğiyle) ve son olarak ise İngilizlerin hâkimiyeti altına girmiştir. Fakat tüm bu dönemler içerisinde nüfusun büyük çoğunluğunu, Müslümanların oluşturduğu görülmüştür. 1891 yapılan nüfus sayımında Müslüman nüfus 814.241 olarak tespit edilmiş, 1921'de ise Müslüman nüfusun 1.407.086'ya çıktı̆̆ görülmüşsür. ${ }^{2}$

Cammu Keşmir'de (kısaca Keşmir), çatışmanın ortaya çıkışı İngiliz yönetimi içerisinde kurulan idari yönetimden kaynaklanmıştır. İngiltere sömürge döneminde Keşmir ile İngiltere arasında özel iç otonomi anlaşmaları yapılan 562 racalık/prenslikten birisi olmuştur. ${ }^{3}$ Tarihsel süreç içerisinde, Hindu Gulab Singh ${ }^{4}$, Keşmir bölgesini 1846 yılında İngiliz East India Company'den para karşılığı satın almıştır. Ticari bir emtia / mal olarak Keşmir'in satılması Keşmirlileri tahrik etmiş, bu durum ise 'Keşmir Aslanı' olarak bilinen Şeyh Abdullah'ın önderliğinde 1931 yılından itibaren hürriyet hareketine dönmüştür. 1946 yılına geldiğimizde hürriyet hareketinin mihraceye karşı olarak geliştiği ve mihracenin Keşmir'i terk etmesinin istendiği görülmüştür. "Keşmir'i terk et" kampanyası kısa süre içerisinde kaçınılmaz olarak silahlı çatışmaya dönmüştür. ${ }^{5} 1947$ yılında İngiltere Hindistan' dan çekilirken ülke Pakistan ve Hindistan adında iki ülkeye bölünmüş, İngilizler sayıları beş yüz kadar olan prenslere, racalara Hindistan veya Pakistan devletlerinden birini seçerek iltihak etmelerini veya bağımsızlığ etmeleri konusunda serbest bırakmıştır. ${ }^{6} \mathrm{Bu}$ racalıklardan birisi olan Keşmir, iki devletten birisine katılmayı tercih etmediği takdirde bağımsız kalacaktı. Bağımsızlığını sürdürmek isteyen Keşmir racası Hari Singh, bağımsızlığın ilanından iki gün önce 13 Ağustos 1947'de Hindistan ve Pakistan'a mevcut durumun devamını sağlayacak anlaşmaların yapılmasını talep etmiş, Pakistan bu talebi kabul etmişse de Hindistan olumsuz cevap vermiştir. ${ }^{7}$ Hindistan Genel Valisi Lord Louis Mountbatten'in Keşmir ziyareti sırasında mihraceye Hindistan'a katılırsa kendisinin tam desteğini ve himayesini alacağı hususunda teminat vermesi, Keşmir'in durumunu etik olmayan bir surette Hindistan lehine değiştirmiştir. ${ }^{8}$ Mihrace Pakistan'la 15 Ağustos'ta gerçekleştirdiği 'hareketsizlik anlaşması'na rağmen Doğu Pencap'tan silahlı Hindu

\footnotetext{
${ }^{1}$ Sa1yı1 Athar Abbas Rızvı, "Keşmir", Türkiye Diyanet Vakfi İslam Ansiklopedisi, Cilt: 25, Ankara, 2002, s. 325.

${ }^{2}$ Azmi Özcan, "Dünden Bugüne Keşmir ve Keşmir Meselesi", Keşmir Dosyası, Yay. Hzr., Halil Toker, TATAV Yayınları, İstanbul, 2003, s. 32-33.

${ }^{3}$ Y1lmaz Altuğ, Başlangıcından Günümüze Keşmir Meselesi, İrfan Yayınevi, 2002, s. 11-12.

${ }^{4}$ Mustafa Dinçer, "Keşmir: Himalaya Eteklerinde Bağımsızlık Mücadelesi”, Dünya Çatışma Bölgeleri, Ed. Kemal İnat, Burhanettin Duran, Muhittin Ataman, s. 660.

${ }^{5}$ Altuğ, age, s. 11-12.

${ }^{6}$ Rizvi, agm, s. 326.

${ }^{7}$ Halil Toker, "Cunagard ve Haydarabad Bağlamında Keşmir'in Hindistan'a İlhakı Üzerine Bir Değerlendirme”, Keşmir Dosyası, Yay. Hzr., Halil Toker, TATAV Yayınları, İstanbul 2003, s. 85.

${ }^{8}$ Altuğ, age, s. 16-17
} 
ve Sihlerin Keşmir'e gelmesini sağlamıştır. Keşmir'de Müslümanlara karşı silahlı unsurların artması ile her türlü mukavemete karşı şiddet uygulanmaya başlanmıştır. ${ }^{9}$ Son gelişmeler üzerine Punc ve Mirpur bölgelerindeki Müslümanlar, Mihraceye karşı ayaklanmışlar, 22 Ekim'de ise Pakistan'ın Kuzeybatı Serhad eyaleti Müslümanları, Keşmir üzerine yürüyerek Müslümanları ve ülkeyi kurtarmak istemişlerdir. Tüm gelişmeler üzerine Mihrace Hindistan yönetiminden yardım istemiş ve 26 Ekim 1947 tarihinde Hindistan'a katılım anlaşmasını imzalamıştır. Hindistan birlikleri vakit geçirmeden Srinagar'a girmiş, çatışmalarda Pakistan topraklarına sıçramıştır. Nihayet 1 Ocak 1949 tarihinde Birleşmiş Milletler (BM) gözetiminde ateşkes imzalanmıştır. ${ }^{10}$

Sorunun BM kontrolünde çözüm bulamayacağ kısa süre içerisinde anlaşılmış ve Hindistan ve Pakistan arasında çatışma sürmeye devam etmiş̧ir. Hint ordusu Pakistan ve Keşmirli Müslümanlar karşısında üstünlük sağlayarak bölgenin üçte ikisini ele geçirmiştir. BM çözüm sağlamak üzere tarafları, bölgede plebisit yapılmasını kabul etmeye davet etmiştir. Hindistan'ın buna karşı bir takım çekinceler ileri sürmesi ise plebisit yapılmasını imkânsız hale getirmiştir. Dünyanın 1950'li yıllarda ABD'nin ve SSCB'nin başını çektiği iki kutba ayrılması, tarafların ve dolayısıyla Keşmir'in Soğuk Savaş'tan etkilenmesine neden olmuştur. SSCB, Hindistan'ın 'Bağlantısızlık' içerisinde yürüttüğü politikalara engel olmazken Pakistan ise Hindistan tehdidi sebebiyle ABD’ye yönelik politikalar geliştirmiş, ABD'nin bölgesel politikalarında rol almıştır. $\mathrm{Bu}$ doğrultuda Pakistan, 1955 yılında ABD öncülüğünde gerçekleşen Bağdat Paktı'na dâhil olmuştur. SSCB'nin ise Pakistan'ı destekleyen ABD'ye karşı Hindistan'ın yanında yer aldığı görülmüş̧ür. Hindistan, SSCB'den aldığı bu destek doğrultusunda 1957 yılında Keşmir'i topraklarına kattığını ilan etmiştir. ${ }^{11}$

1960 y1llarda Soğuk Savaş’ta yaşanan ‘yumuşama dönemi’nin etkisi Güneydoğu Asya'da yaşanan Hindistan-Pakistan çatışmasına da yansımıştır. 1963-1964 arasında Hindistan yönetimi Keşmir'i yasal olarak ilhak edebilmek için anayasal bir düzenlemeye gitmiştir. ${ }^{12}$ Keşmir'de sona ermeyen gerilim, BM'de sağlanamayan çözüm ve Soğuk Savaş'ta yaşanan 'detant' dönemi, 1963 yılı itibariyle Keşmir üzerinde Hindistan-Pakistan çatışmasını hızlandırmıştır. 1963 yılından sonra 1965 yllına geldiğimizde Keşmir sorununun her iki devlet arasında bir savaşa döndüğü görülmüş̧ür. 1965 yılının Nisan ayında Sind-Gujarat sınır bölgesinde Pakistan ve Hindistan kuvvetleri arasında küçük bir çatışma çıkmış, fakat kısa süre içerisinde bu çatışma Pencap sınırına kadar genişlemiştir. Haziran ayına gelindiğinde çatışma Pakistan-Hindistan savaşına dönüşmüştür. Savaş, varılan ateşkes anlaşmasıyla sona ermiş, SSCB'nin girişimiyle her iki taraf Taşkent'te bir araya gelmiştir. ${ }^{13}$ Özbekistan'ın başkenti Taşkent'te 4 Ocak 1966 tarihinde bir araya gelen Hindistan ve Pakistan tarafları, yapılan müzakereler neticesinde 5 Ağustos 1965 yılından önceki mevzilerine dönmeyi kabul etmiştir. Ayrıca iki ülkenin birbiri aleyhine faaliyet göstermeyeceği, anlaşmazlıkların ise görüşme yoluyla çözülmesine çalışılacağı ve iki ülke arasında ticari, kültürel ilişkilerin geliştirilmesine çalışılacağı maddeleri kabul edilmiştir. ${ }^{14}$ Fakat Taşkent'te imzalanan anlaşmaya rağmen sorunlar tamamen çözüme kavuşturulamamış, Hindistan ve Pakistan 1971 yılında yeniden karşı karşıya gelmiştir. ${ }^{15}$

\footnotetext{
${ }^{9}$ Pakistan Sefareti Basın Ataşeliği, Keşmir Meselesi, Ankara, La Turquie Modern Basımevi, İstanbul 1952, s. 14

${ }^{10}$ Özcan, agm, s. 32-33.

${ }^{11}$ Dinçer, agm, s. 663.

${ }^{12}$ Emrin Çebi, Keşmir Raporu: Tarihî Süreç ve Bölgeye Dair Çözüm Önerileri, Araştırma 75, İNSAMER, Ağustos 2018, s. 16.

${ }^{13}$ Tayyar Arı, Global Politika ve Güney Asya Keşmir Sorunu ve Nükleer Yarış, Alfa Basım Yayım, 2. Baskı, 2000, s. 86.

${ }^{14}$ Fahir Armaoğlu, 20. Yüzyıl Siyasi Tarihi 1914-1995, Alkım Yayınevi, 14. Baskı, s. 663.

${ }^{15}$ Dinçer, agm, s. 664.
} 


\title{
2. Türkiye'nin Yaklaşımı Çerçevesinde Keşmir Meselesi
}

1965 yılında Hindistan ve Pakistan arasında yaşanan savaş, tüm dünyanın olduğu gibi Türkiye'nin de ilgisini çekmiştir. Türkiye, Keşmir meselesini ya da Hindistan-Pakistan çatışmasını birden fazla konu sebebiyle oldukça dikkatli takip etmiştir. 1960'lı yıllarda başlayan Kıbrıs sorununun Keşmir'le benzerlik kurulacak bir mesele gibi görülmesi, Hindistan'ın Kıbrıs konusunda Rum yönetimini desteklemesi, ayrıca Pakistan'ın Türkiye'nin 'ebedi dostu' olması ve Türkiye'nin ABD öncülügünde Pakistan ile Bağdat Paktı/CENTO'da müttefik olması gibi konular bu dönemde Türkiye'nin ilgisini Keşmir'e yöneltmiş̧ir. Bu durum Başbakanlık makamının konuyla yakından ilgilenmesine ve birtakım özel raporların hazırlatılmasına neden olmuştur. Keşmir ve Hindistan-Pakistan çatışmaları konularında hazırlanan raporlarda ilk dikkat çeken detay, kamuoyunun beklentisinin aksine Türkiye'nin meseleyi taraf olmaktan çok bağımsız bir şekilde ele almış olmasıdır. Türkiye, Keşmir konusunda Pakistan'ın yanında yer almışsa da bu durumun Türkiye'nin bağımsız bir şekilde hareket etmesine engel olmamasına özellikle dikkat edilmiştir. Bu durum ise Türkiye'nin Keşmir meselesine bakışını konjonktürel bir zeminde değerlendirmesine sebep olmuştur. Türkiye ile Pakistan arasında 2 Nisan 1954'te imzalanan Karaçi Antlaşması olarak da bilinen ve Türkiye-Pakistan Dostane İşbirliği Antlaşması, Türkiye'nin Keşmir konusunu değerlendirmesinde etkili olmuştur. Karaçi Antlaşması, Türkiye'nin Keşmir Meselesi'ne bakışında tartışma ve yorumlara sebep olmuştur. Zira Karaçi Anlaşması ile birlikte Pakistan ile Türkiye arasındaki ittifak yapısı perçinlenirken diğer taraftan da Pakistan, Türkiye vasıtasıyla ABD’ye yakınlaşmıştır. ${ }^{16}$

İlginç bir biçimde Türkiye, Keşmir Meselesini tarihsel olarak 1947 olayları ile başlatmıştır. Pakistan ve Hindistan'ın iddiaları daha eski tarihlere gitmekte iken Türkiye, 1965 yılı itibariyle sorunu, Pakistan ve Hindistan'ın İngiltere'den bağımsızlıklarını kazanarak müstakil devletler olmalarıyla başlatmış, meseleyi dinsel bir ayrışmadan daha ziyade iki devletin sınır sorunları olarak tasnif etmiştir:

\begin{abstract}
“1947'de Pencap'ta başgösteren kargaşalıklar, Mihracesi Hint'li fakat ahalisinin 3/4'ü Müslüman olan Keşmir'e de sirayet etmiștir. Patlak veren isyan Kuzey Batı așiretleri tarafindan da desteklenince Mihrace .Keşmir'i Hindistan'a ilhak etmek istemiş ve Hindistan da, normal şartları avdetinde serbest bir plebisit yapılmak kaydıyla ilhakı kabul ve Keşmir'in hükümet merkezini korumak üzere askerî birlikler sevketmiştir. Bu hareket tarzl, ahalisinin terekküp şekli ve coğrafì ve ekonomik bağları dolayısiyle Keşmir'i ilhak etmek isteyen Pakistan'da infial uyandırmıştır. Keşmir'de mücadele devam etmiş ve Ocak 1948'de Pakistan ve Hindistan Birleşmiş Milletler Güvenlik Konseyine başvurmuşlardır. Birleşmiş Milletler 1949 senesinden 1959'a kadar daimî olarak Keşmir meselesine bir hal çaresi bulunmasına çalışmış ve muhtelif teşebbüsler yapmıştır. ",17
\end{abstract}

Türkiye, Keşmir sorununu 1965 yılında yaşanan çatışma ve öncesi olarak iki merhalede; 1947-1959 ve 1960-1965 dönemi olarak ele almıştır. Türkiye, ikinci dönemde Hindistan ve Pakistan'ın konuyu siyasi anlaşma ve taksim tezleri üzerinden sürdürdüğü değerlendirmesinde bulunmuş̧tur. Türkiye'nin görüşüne göre Hindistan ve Pakistan arasında taksim hususunda sınır olarak Hindistan'ın ateşkes hattını teklif etmesi, Pakistan'ın ise Ladak ve Cammu'yu bırakabileceklerini ima etmeleri, iki devlet arasındaki görüş farkının Keşmir Vadisi ile sınırlı olduğunu göstermektedir. Türkiye'ye göre Keşmir'in çözümü için Hindistan plebisit yapılması taraftarı olmuş, fakat plebisitin yapılmaması için ise elinden geleni gerçekleştirmiştir. Diğer

\footnotetext{
${ }^{16}$ Selma Göktürk Çetinkaya, "Bağdat Paktı'nın Kuruluş Sürecinde Türkiye'nin Ortadoğu ve Batı İle İlişkileri", Vakanüvis Uluslararası Tarih Araştırmaları Dergisi, C.1, S. Ortadoğu Özel Sayısı, 2016, s., 6.

${ }^{17}$ BCA (Devlet Arşivleri Başkanlığ 1 Cumhuriyet Arşivi), 30-1-0-0 / 64-395-12, Pakistan ve Hindistan arasında hudut ihtilafları ve Kutch bataklığı olayları hakkında rapor, 24.05.1965.
}

\section{History Studies}


taraftan Pakistan'ın ise ilk günkü heyecanını muhafaza ettiği ve haklı davasından hiçbir tavize meydan vermeyeceği anlaşılmıştır. ${ }^{18}$

Keşmir konusunda Türkiye, Hindistan'ın iddialarını şu şekilde tespit etmiştir;

- Keşmir Mihracesi 26 Ekim 1947 tarihinde aldığ bir kararla Hindistan'a iltihak etmiştir. Genel Valinin onaylamasıyla birlikte iltihak fiilen ve hukuken tahakkuk etmiştir.

- Mihracenin imzası ve Genel Valinin onaylamasıyla birlikte Pakistan, Keşmir konusunda "mütearrız" bir devlet mevkiine düşmüştür.

- Keşmir'de Hint kuvvetlerinin yer alması, Hindistan topraklarının meşru müdafaasından kaynaklanmaktadır.

- Pakistan tarafından ileri sürülen plebisit mevzuunda Hindistan Hükümetinin bir itirazı yoktur; ancak plebisit yapılabilmesi için Pakistan silahlı kuvvetlerinin, kabilelerinin çekilmesi ve Azad Keşmir birliklerinin dağıtılmaları gerekmektedir.

- Birleşmiş Milletler Güvenlik Konseyinin kararları (değişen şartlar) muvacehesinde muteberiyetini kaybetmiştir. Değişen şart olarak Hindistan, Pakistan'ın başka devletlerle askeri paktlar akdettiğini ve silâh yardımı almış bulunduğunu, ayrıca Hindistan'ın toprakları sayılan Keşmir'den Çinliler ile yaptığı müzakere neticesinde 2 bin mil karelik bir araziyi Çin'e terkettiğini ileri sürmektedir.

- Keşmir ihtilâfı ancak Hindistan ve Pakistan arasında siyasî bir anlaşma ile halledilebilir. Böyle bir anlaşmanın esası ise Keşmir'in taksimidir ${ }^{19}$

Hindistan'ın Keşmir hakkındaki iddialarına benzer bir şekilde Pakistan'ın iddialarına da yer veren Türkiye, Keşmir konusunda bağımsız bir görüş ortaya koyarak konunun tüm detaylarını belirlemek istemiştir. Türkiye tarafından kayda geçirilen Pakistan'ın iddiaları ise şu şekildedir;

- Pakistan Keşmir üzerinde herhangi bir hak iddia etmemektedir ve Keşmir'i ilhak arzusunda değildir. Pakistan, yalnızca Keşmir halkının hangi devlete iltihak etmek istediğini serbestçe ifade edebilmek imkânının verilmesini istemektedir.

- Keşmir Mihracesi 15 Ağustos 1947 tarihinde Pakistan ile "statu quo anlaşması" imza etmiş ve bu suretle diğer bir devletle anlaşmaya veya müzakereye girmemeyi taahhüt etmiş bulunmaktaydı. Mihrace iltihaknameyi imzaladı̆̆ 1 tarihte, Keșmir'i terk ederek Hindistan'a firar etmiş haldeydi. Hindistan Genel Valisi İltihaknameye karşılık yazdığı mektupta Keşmir'de asayiş müsait olur olmaz plebisit yapılmasını talep etmiştir.

- Keşmir'deki Azad kuvvetleri Keşmir ahalisinin meşru müdafaa hareketidir. Ayrıca Pakistan Silahlı Kuvvetleri'nin Keşmir'de bulunması, Pakistan'ın meşru müdafaa haklarından doğmaktadır. Pakistan Silahlı Kuvvetleri, Hindistan'ın Keşmir'i tamamen işgal etmesine engel olmak ve Pakistan'a doğru yürüyen Hint kıtalarını durdurmak için Keşmir'e girmiştir. ${ }^{20}$

Türkiye, Keşmir konusunda objektif bir değerlendirmede bulunmak üzere iki tarafın da görüşlerine yer vermiştir. Hindistan, Keşmir sürecinin hukuki olduğu savını ileri sürerken, Keşmir'de Hint kuvvetlerinin bulunmasını ise meşru haklarından kaynaklı olduğunu ifade etmiştir. Hindistan, plebisit yapılmasına itiraz etmezken plebisitin yapılması için Pakistan ve Azad Keşmir birliklerinin dağıtılmasını şart koşmuştur. Ayrıca Hindistan'ın Keşmir meselesini uluslararası bir hale getirdiği, Çin meselesini de Pakistan'la ilintilendirdiği görülmüştür. Hindistan'a göre çözüm siyasi taksimden geçmektedir. Pakistan ise Azad kuvvetlerini meşru müdafaa hareketi olarak görürken, yapılmayan plebisitin yapılması ısrarında bulunmuştur.

\footnotetext{
${ }^{18}$ BCA, 30-1-0-0 / 64-395-12, Kutch bataklı̆̆ı olayları, 24.05.1965.

${ }^{19} \mathrm{BCA}, 30-1-0-0$ / 64-395-12, Kutch bataklığ

${ }^{20}$ BCA, 30-1-0-0 / 64-395-12, Kutch bataklığı olayları, 24.05.1965.
} 
Pakistan'ın Keşmir'e girmesi ise Pakistan'ın meşru müdafaa hakkı olarak değerlendirilmiştir. Pakistan, sorunu basitçe meşru plebisit hakkının sağlanması noktasında savunurken, Hindistan'ın meseleyi siyasallaştırıp karmaşıklaştırdığı görülmüştür.

Türkiye'ye göre Keşmir Meselesi’nin meydana getirdiği gergin atmosfer içerisinde iki devletin ilişkileri bir türlü düzelmemiș, Hindistan'daki Müslüman aleyhtarı olaylar esnasında beş yüz hadise vuku bulmuş 1950'den sonra binlerce Müslüman ölmüştür. İngiliz ve Amerikalılar iki tarafın da çözüme yanaşması için girişimlerde bulunmuşsa da süren olaylar bu tür çabaları başarısız kılmıştır. 1965 Savaşı öncesinde gergin olan atmosfer, çözümü imkânsız bir hale getirirken aynı zamanda, Hindistan'ın yerel yönetim düzeyinde Keşmir'de yaptığ 1 değişiklikler gerginliği tırmandırmıştır. Keşmir Parlamentosu ve valilik makamında yaptığ değişiklik dışında Hindistan'ın son olarak Keşmir Müslüman Lideri Şeyh Abdullah'1 hac farizası dönüşünde tutuklayarak sürgüne göndermesi çözümsüzlügün Keşmir'de çatışmaya dönmesine neden olmuştur.

Mayıs ayında henüz Hindistan ve Pakistan arasında çatışmanın yoğun olarak yaşanmadığı bir dönemde, Türkiye'nin Keşmir hakkındaki görüşü ilk olarak Sovyet/ Komünizm endişesi etrafında şekillenmiştir. Türkiye, Hint Yarımadasının Rusya ve Çin tarafından Komünist saldırıya uğrayacağı endişesi ile konuyu oldukça kaygılı bir şekilde ele almıştır. Türkiye'nin Keşmir meselesi değerlendirmesindeki ikinci faktör ise bölge barışı olmuştur. Türkiye, bu dönemde 'dost ve kardeş' olarak nitelendirdiği Pakistan ile Hindistan'ın arasındaki gerginliğin çözülmesini arzu etmiştir. Türkiye'nin çözüm arzusu Pakistan'ın veya Keşmirlilerinde durumundan daha çok yine kayg1 duyduğu komünizm endişesinin bölgeye yerleşmesi tehlikesinden kaynaklanmaktadır. Pakistan'a ehemmiyet vermekle birlikte Türkiye'nin önceliğinin tarafı olduğu, cephe savaşı olduğu görülmektedir. Türk dış politikası, Pakistan'1 Keşmir konusunda haklı görmekte ve desteklemekte iken sorunun iki ülke dışında üçüncü bir ülkenin müdahalesine imkân vermeyecek şekilde 'barışçı ve hakkaniyete dayanan yollarla iki tarafı mümkün olduğu kadar tatmin edici şekilde halledilmesini' istemektedir. Fakat hakkaniyet ve iki ülkenin de tatmin olması meselesi oldukça belirsiz bir istek olarak kalmıştır. Türkiye, bu dönemde Pakistan'ı kamuoyunun arzusu yönünde desteklemekte ise de dış politikanın gereği olarak açıkça dâhil olduğu NATO'nun hilafına davranamayacak bir politika izlemek durumunda kalmıştır. Türkiye 1962 yılında Çin-Hindistan ihtilafı dolayısıyla, Hindistan'dan silah yardımı talebi almış, fakat kamuoyunun gereği olarak "Pakistan'ın hissiyatını anlamış ve silâhların teslimi kararlaştırıldığı halde son anda vermekten vazgeçmiştir." Türkiye, bir yandan ABD'nin arzusu doğrultusunda Çin'in bölgeye yerleşmesini önlemek isterken bir taraftan ise 'dost ve kardeş' Pakistan'ı yalnız bırakmak istememektedir. Türkiye, NATO üyesi olması ve aynı zamanda Pakistan ile kadim bağlara sahip olması hasebiyle 1962 yılının Kasım ayında Pakistan ile Hindistan arasında arabulucu rolü oynamıştır. İki tarafında Türkiye'nin arabuluculuğunu kabul etmeleri ile 1962-1963 yıllarında müzakereler gerçekleşmiş, fakat bir netice alınamamıştır. ${ }^{21}$ Türkiye'nin Keşmir Meselesine bakışını son olarak Hindistan ile 1955 yılında Bandung Konferansı sırasında yaşadığ arasında arabulucu bir rol alan Türkiye, Hindistan-Pakistan arasındaki sürece katkı sağlamak isterken bir diğer taraftan da Hindistan'la 1955 yılında Bandung'da bozulan ilişkilerini düzletmek istemiştir.

\footnotetext{
${ }^{21}$ BCA, 30-1-0-0 / 64-395-12, Kutch bataklığı olayları, 24.05.1965.

${ }^{22}$ Armaoğlu, age, s. 624-625.
} 


\section{1965 Savaşı'na Giden Süreç}

Keşmir'deki, ateşkes çizgisinde 1964 yılı içinde iki ülke birlikleri arasında çeşitli çatışmalar çıkmış ve bu çatışmalar 1965 yılının ilk aylarında şiddetlenmeye başlamıştır. Hindistan ve Pakistan Nisan 1965'te Rann Kutch bölgesindeki birliklerini güçlendirmişlerdir. 5 Ağustos 1965'te Pakistan askerleri, Hindistan' in elinde bulunan Keşmir'e geçmiş, Hindistan ise bu geçişi engellemek üzere Pakistan sınırı içerisindeki bazı stratejik noktaları işgal etmiştir. Pakistan, Keşmir-Hindistan bağlantısını kesmek üzere Cammu bölgesine saldırı düzenlerken Hindistan Eylül ayında Pakistan'a karşı üç kollu bir saldırıya geçmiştir. Çatışmalar BM'nin 23 Eylül tarihli ateşkes çağrısıyla sona ermiştir. ${ }^{23}$ Tarihsel süreç içerisinde 1965 yılında yaşanan savaşı, her ne kadar Pakistan'ın başlattığı iddia edilse de Halil Toker'e göre bu değerlendirme son derece yanlış ve hatalıdır. Zira Toker, Pakistan'ın ABD'den CENTO kapsamında aldığı silahlarla üstün olduğunu düşünerek harekete geçtiği iddiaları karşısında göz ardı edilen en önemli detayın Hindistan'ın Pakistan'ın iki katı yardımı hem SSCB'den hem de ABD'den aldığını söylemektedir. Toker'e göre ayrıca, İngiliz askeri gücünü devralması Hindistan'ın Pakistan karşısında gücünü katlamasını sağlamıştır. Hindistan'ın askeri avantajı göz önüne alındığında Pakistan'ın böyle bir savaşa girmesinin tehlikeli bir seçenek olduğu görülmektedir. Toker, Pakistan'ın Keşmir'e operasyon düzenlemesi için 1965'ten daha önce, 1962 yılında Hindistan-Çin savaşı sürerken Hindistan'ın ordusunun yenilgiye uğradığı bir sırada operasyon düzenlemesinin daha uygun olduğunu ifade etmektedir. Pakistan'ın durumu saldırıdan daha çok müdafaa şeklinde gerçekleşmiştir. Bu doğrultuda Hindistan-Pakistan savaşı Mayıs 1965'te Hindistan'ın Pakistan sınırına yaptığı müdahaleler ile ateşlenmiştir. Mayıs ayında Hindistan Rann-Kutch bölgesindeki Pakistan karakollarına saldırmış, Haziran ayında ise Pakistan hava sahasını ihlal etmiştir. ${ }^{24}$

\subsection{Türkiye'nin Savaş İçerisindeki Tutumu}

Türkiye'nin Hindistan ve Pakistan hudut sorunları ile Rann-Kutch bölgesinde gerçekleşen olayları dikkatlice takip ettiği görülmüştür. Türkiye'nin sınır sorunları konusunda Pakistan'a hak verdiği, Keşmir Sorunu ile ilgili hazırlanan raporda belirtilmiştir. Buna göre Hindistan, ihtilaflı bir bölge olması dolayısıyla Keşmir'e verilen özel statüyü sona erdirip, Keşmir'i tamamen ilhak etmek istemektedir. Hindistan'ın Keşmir'i ilhak etmek üzere giriștiği gayretler ise dünya kamuoyunda olumsuz tepkiler meydana getirmektedir. Hindistan, dünya kamuoyunun dikkatini dağıtmak ve "Pakistan'ı Hint topraklarına tecavüzle itham etmek imkânını bulmak üzere" Keşmir dışındaki ortak sınırlarda sorun çıkarmaktadır. Rapora göre, Hindistan'ın bu tür bir eylem içerisine girmesinin başka sebepleri de vardır. Hindistan'ın yaşadığı ekonomik zorluklar, Başbakanı Şastri'nin ülke içerisinde yaşadığı prestij sorunları bu tür sebepler arasındadır. Ayrıca rapora göre Hindistan, Pakistan ile 'Kızıl Çin' komplosu karşısında bulunduğu intibaını vererek ABD'den almakta olduğu yardımı arttırmaya çalışmaktadır. ${ }^{25}$

Rapora göre Pakistan, Dahagram ve Kutch gibi topraklarda vatandaşlarının haklarını, Hindistan müdahalesine karşı korumuş, buna karşı bir takım çatışmaların yaşanması sonucunda ise Hindistan propaganda yoluyla yurt dışı temsilcilikleri vasıtasıyla Pakistan aleyhinde geniş bir faaliyet göstermiştir. Mayıs, Haziran ve son olarak da Ağustos ayında yaşanan gelişmelerden sonra, Eylül 1965 tarihinde sivillerin yoğun olarak yaşadığ 1 Lahor şehrine tank, top ve uçaklarla saldırmaya başlamış, Hindistan'ın saldırısı sonucunda aynı gün savaş tüm

\footnotetext{
${ }^{23}$ Oral Sander, Siyasi Tarih Birinci Dünya Savaşının Sonundan 1980’e Kadar, İmge Kitabevi, Ankara 1989, s.380.

${ }^{24}$ Halil Toker, Sebepleri ve Sonuçları İle Keşmir Meselesini Kavramak, Demavend Yayınları, İstanbul 2017, s. 9395.

${ }^{25}$ BCA, 30-1-0-0 / 64-395-12, Kutch bataklığı olayları, 24.05.1965.
}

\section{History Studies}

HISTORY ST UDIES 
Hindistan-Pakistan sınırı boyunca yayılmıştır. ${ }^{26}$ Türkiye Dışişleri Bakanı Hasan Işık, Hindistan'ın saldırısından kısa bir süre önce çatışmanın artması üzerine yaptığı açıklamada, olayların gelişmesinin endişe verici olduğunu vurgulayarak konunun adil, barışçı ve taraflar arasında tatminkâr bir surette çözülmesi gerektiğini vurgulamıştır. ${ }^{27}$

Haziran ayından Eylül ayına kadar gelen süreçte Türkiye, Keşmir meselesinin durumu ile ilgili bir değerlendirmede bulunmuştur. Bu değerlendirme ekseninde Türkiye'nin çatışmanın boyutunun arttığ 1 Ăgstos ayını statükonun bozulması sebebiyle milat olarak kabul ettiği görülmüştür. Hindistan ve Pakistan'ın bu süreçteki görüşlerine yer veren Türkiye, Pakistan'ın bu dönemki iddialarını şu şekilde belirtmiştir:

\begin{abstract}
"Keşmir'de bir müddetten beri ayaklananlar olmaktadır. Aslında bu ayaklanmalar yeni değildir. Bunlar 1931 senesine kadar geriye gider. Hindistan Hükümeti Keşmir meselesinin sulhcu yollarla halledilmesine ve Birleşmiş Milletlerin bu meseledeki kararlarını uygulamaya yanaşmadıktan başka

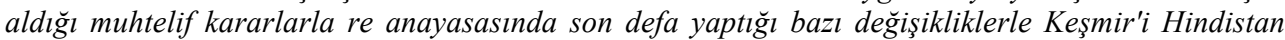
birliğine ilhak etmek istemişstir. Memleketlerinin Sulhcu yallarla millî mukadderatına kavuşması iğin 18 yıldan bari yaptığ mücadelenin başarısından artık ümidini kesen Keşmir halkı, bu uğurda fiilen mücadeleye girişmek kararına varmıştır. 8 Ağustos günü Sedâyı Keşmir (Keşmir'in sesi) isimli gizli bir radyo istasyonu emperyalizme karşı ayaklanacağını ilân ederek bir İhtilâl konseyinin kurulduğunu, bundan böyle Hindistan Hükümetine vergi ödenmesinin yasak edildiğini, vergilerin bu konseye ödenmesi gerektiğini bildirmiştir. Keşmir halkı aynı zamanda kendi mukadderatını tesbit işin Hint idaresine karşı ayaklanmıştır. Bu ayaklanma silâhlı bir ayaklanmadır ve Keşmirli mücahitler, tanınmış lider Şeyh Abdullah'ın, Hindistan Hükümetince tevkif edilmiş olmasından duydukları İnialin de tesiri ile böyle bir silâhl mücadeleyi yürütmeye zorlanmış bulunmaktadırlar. Bu itibarla hareketleri milli ve meşru bir hareket niteliği taşımaktadır." 28
\end{abstract}

Keşmir meselesini Pakistan açısından değerlendiren Türkiye, Hindistan'ın görüşlerini de dikkate almıştır. Hindistan'a göre barışı Pakistan, 5 Ağustos tarihinde Keşmir'deki ateşkes hattına girerek bozmuştur. Hindistan'ın kontrolü altındaki bölgeye giren Pakistanlılar ayaklanmayı teşvik ve tahrik etmişlerdir. Hindistan'ın en önemli ikinci iddiası ihtilal konseyi kurulduğu haberinin asılsız olduğu ve bunların Pakistan kökenli olduğudur. Hindistan'ın ifadelerinden Keşmir'de bir konsey kurulmasının Hindistan'1 endişelendirdiği görülmüştür. Zira benzer bir biçimde Hindistan, Sâdayı Keşmir radyosunun Hindistan'ın kontrolü altındaki topraklardan değil Pakistan'dan gerçekleştirildiğini ifade etmiştir. Hindistan'a göre olayları Keşmirliler değil Pakistanlılar çıkarmış ve halk buna sempati göstermemiştir. Hindistan'a göre olaylar sırasında Pakistan'ın topçu atışıyla sınır ötesinden müdahalede bulunması üzerine Hindistan harekete geçmiştir. Hindistan Başbakanı Şastri olaylar üzerine yaptığı açıklamada Hint birliklerinin ateşkesi temin maksadıyla ateşkes hattını geçtiğini ve icap ederse Hint birliklerinin daha da ileri giderek gerekli önlemleri almaktan kaçınmayacaklarını bildirmiştir. ${ }^{29}$

Ağustos ayında başlayan olayların Eylül ayına giden süreçte daha fazla büyümediği görülmüştür. 1 Eylül'e geldiğimizde konuyla ilgili olarak hazırlanan raporda, Hindistan'ın ateşkes hattını geçerek Pakistan'ın müdahalesini engellemesi üzerine Pakistan'ın desteklediği Hür Keşmir Kuvvetleri'nin harekete geçtiği, Pakistan'ın ise Keşmirlilerin haklarını korumak üzere destek verdiği ortaya çıkmaktadır. Askeri ilerlemenin sonraki detayları raporda elde edilen bilgiler 1şığında şu şekilde gerçekleşmiştir: Hindistan'a göre Hintliler Paton tipi 13 Pakistan tankını saf dışı etmiş ve 3 Eylül'de de bir Pakistan jetini havada iken imha etmişlerdir. Pakistan'dan derlenen bilgilere göre ise Pakistan, dört Hindistan jetini düşürmüş, Hint

\footnotetext{
${ }^{26}$ Toker, Keşmir Meselesini Kavramak, s. 94.

27 BCA, Fon Kodu: 30-1-0-0 / 64 -396 - 10, Dışişleri Bakanı Hasan Işsk’ın Keşmir meselesine ait beyanatı, 06.09.1965.

${ }^{28}$ BCA, Fon Kodu: 30.1.0.0 / 23 - 131 - 12, Keşmir olayları ve Pakistan-Hindistan silahlı çatışmasıyla ilgili rapor, 03.09.1965.

${ }^{29}$ BCA, Fon Kodu: 30.1.0.0 / 23 - 131 - 12, Keşmir olayları ve Pakistan-Hindistan silahlı çatışması, 03.09.1965.
} 
birliklerini püskürtmüş ve 2 Eylül'de Keşmir'in Hint kontrolü altında kesiminin otuz mil kadar içine girmişler ve Cammu'dan sadece 15 mil mesafede bulunan büyük stratejik ehemmiyeti bulunan Aknur şehrine ulaşmışlardır. ${ }^{30}$

Gerek Hint kaynaklarından gerekse Pakistan kaynaklarından yararlanılarak hazırlanan raporda Pakistan'ın Hindistan üzerinde baskı kurarak hızla ilerlediği görülmüş̧ür. Gelişmeler üzerine ABD, İngiltere ve Türkiye kısa süre içerisinde ateşkesi tesis etmek üzere devreye girmişse de bunun hemen sağlanamadığı görülmüş, ateşkes için Eylül ayının son günlerini beklemek gerekmiş̧ir. Pakistan açısından yaşananları değerlendiren rapora göre Pakistan, "Keşmir meselesinin özellikle Birleşmiş Milletler yolu ile bir hal tarzına bağlanmasında rastlanan sürüncemenin verdiği usanç ve sabırsızlı haleti ruhiyesi içinde emperyalizm diye tavsif ettiği Keşmir davasını silaha başvurmak sureti ile ve millî imkânları ile halletmek çabasına girmiştir." 31 Rapora göre Pakistan'ın Keşmir'de yaşananlar ve çözümün bir türlü sağlanamaması sebebiyle fiili mücadele yoluna sapması, beklenen bir gelişmeydi. Hindistan ise Keşmirlilerin plebisit hakkına bir itirazda bulunmamakla birlikte plebisitin yapılmasını sağlamak üzere Pakistan'ın silahlı Keşmir kabilelerinin, Hür Keşmir Birliklerinin Keşmir'i terk etmesi gerektiği ileri sürmüştür. Bunun yanı sıra Hindistan, plebisit yerine Keşmir meselesinin Pakistan'la yapılacak bir siyasi anlaşmayla sağlanabileceğini düşünmektedir. Zira Hindistan'a göre Pakistan, bir takım askeri paktlara dâhil olmuş ve silah yardımı almıştır ve "Hint toprağ 1 sayılan Keşmir'den" Çinlilere 2.000 mil karelik araziyi terk etmiştir. Hindistan, Keşmir meselesinin taksim esaslı yapılacak bir siyasi anlaşmayla halledileceğini düşünmektedir. Türkiye'nin her iki tarafın görüşleri üzerine yaptığı değerlendirmede ise Hindistan'ın çözüme yanaşmamak üzere hareket ettiğini şu şekilde belirtmiştir; "Görüldüğü üzere, daha ziyade fiilî durumlardan hareket eden ve Hindistan yarımadasının taksimine esas teşkil eden din faktörünü ve Keşmir halkının self-determination hakkına nazarı itibara almayan Hindistan görüşü, bazı stratejik mülâhazaların oynadığl rolün de tesiri altında, Pakistanla müspet ve verimli olabilecek müzakerelere yanaşmamaktadır. "32

Hindistan'ın Pakistan ile çatışması şüphesiz uluslararası gelişmelerin gölgesinde şekillenmiştir. Bu durumun en bariz göstergesi, Hindistan'ın Pakistan'ın askeri paktlara üye olmasından duyduğu rahatsızlığı dile getirmesidir. Fakat askeri paktlar Pakistan'a Keşmir konusunda herhangi bir katkı sağlamamıştır. $\mathrm{Bu}$ açıdan Keşmir meselesini değerlendirdiğimizde Pakistan'ın CENTO'ya üye olmasının Keşmir'de Pakistan için çözüm getirmediğini aksine Hindistan'ın Pakistan karşısında daha rahat hareket etmesini sağladığ 1 görülmüştür. 1965 dönemi için ABD açısından Hint alt kıtasında en önemli tehdit, SSCB'nin bile bir adım önünde olan 'Komünist Çin' tehlikesidir. ABD, Çin tehdidi karşısında Hindistan ve Pakistan'ı aynı kefeye koyan bir anlayış içerisinde olmuştur. Üstelik Pakistan'ın Çin'le yakın bir tutum içerisinde olduğunun düşünülmesi, ABD'nin Hindistan karşısında CENTO dâhilinde Pakistan'ı himaye eder bir pozisyondan uzak durduğu görülmüştür. ${ }^{33}$ ABD'nin Çin tehlikesi karşısında Çin'i dengelemek üzere Hindistan'ı denge unsuru olarak kullanmak istemesi, Pakistan'ın Hindistan karşında ABD'den beklediği desteği görmesini engellemiştir.

\subsection{Türk Dış Politikası ve Keșmir Meselesi}

Tarihsel süreçte dostluk ilişkileri içerisinde bulunan Türkiye ve Pakistan ilişkilerinin Keşmir meselesini kapsaması hiç kuşkusuz beklenen bir gelişmedir. Zira her iki ülkenin birbiriyle olan geçmişi, dünyada pek az örnek olarak görülecek tarzda her koşulda birbirini desteklemek

\footnotetext{
${ }^{30}$ BCA, Fon Kodu: 30.1.0.0 / 23 - 131 - 12, Keşmir olayları ve Pakistan-Hindistan silahlı çatışması, 03.09.1965.

${ }^{31}$ BCA, Fon Kodu: 30.1.0.0 / 23 - 131 - 12, Keşmir olayları ve Pakistan-Hindistan silahlı çatışması, 03.09.1965.

${ }^{32}$ BCA, Fon Kodu: 30.1.0.0 / 23 - 131 - 12, Keşmir olayları ve Pakistan-Hindistan silahlı çatışması, 03.09.1965.

${ }^{33}$ BCA, Fon Kodu: 30.1.0.0 / 23 - 131 - 12, Keşmir olayları ve Pakistan-Hindistan silahlı çatışması, 03.09.1965.
} 
üzerine gelişmiştir. Türkiye ile Pakistan arasında 1954 yılında imzalanan dostluk ve İşbirliği anlaşması, Pakistan'ın 1955 yılında Bağdat Paktı / CENTO'ya dâhil olması neticesinde Türkiye-Pakistan ilişkileri askeri, teknik, stratejik bir boyut kazanmıştır. ${ }^{34}$

Her iki ülkenin de CENTO üyesi olması, Türkiye'nin Pakistan'a tarihsel ve kültürel bağlarla bağlı olması, Türk dıș politikasının bu dönemde Keșmir meselesini dikkate almasını gerekli kılmıştır. Türkiye'nin 1965 yılında Pakistan-Hindistan arasında yaşanan savaşı ve Keşmir meselesini; Kıbrıs, NATO ve tarihsel Pakistan ilişkileri bağlamında ele aldığı görülmüsstür. Bu dönemde SSCB ve ABD arasında yaşanan yumuşama/detant sebebiyle Hindistan'ın Bağlantısızlar olarak bilinen ABD ve SSCB'ye alternatif hareketin önde gelen ülkelerinden olması ve Kıbrıs Cumhurbaşkanı olan Makarios'un Hindistan tarafindan desteklenmesi ve BM başta olmak üzere uluslararası alanda 'Bağlantısızlar' sebebiyle Makarios'un destek görmesi, Türkiye'yi detant döneminde Bağlantısızlara ve dolayısıyla Hindistan'a yaklaştırmıştır. Bu durumun meydana gelmesinde Türkiye ile ABD arasında 1964 yılında Kıbrıs sebebiyle yaşanan Johnson Mektup krizi önemli bir etken olmuştur. Türk dış politikasında önemli bir kırılma anı olan Johnson Mektubu, sonrasındaki süreçte Türkiye'ye, ABD ile yaşadığı sorun çerçevesinde Bağlantısızlar gibi yeni arayışlar içerisine girmeye sevk etmiştir.

1965 Hindistan-Pakistan Savaşı'ndan bir y1l önce Türkiye, Hindistan'la Kıbrıs konusunda temas sağlamak üzere harekete geçmiştir. Bu çerçevede 27 Kasım 1964 tarihinde Türkiye Büyükelçisi, Hindistan Başbakanı Shastri'yi ziyaret ederek Kıbrıs konusunu gündeme getirmiş, Başbakan ise iki tarafı da tatmin etmeyecek bir çözümün uygun olmadığını, Hindistan'ın Kıbrıs bağımsızlığını devam ettirilmesi taraftarı olduğunu ifade etmiştir. Kıbrıs'ın Yunanistan'la birleşme iddialarına karşı Hindistan'ın bağımsızlık tutumu oldukça önemlidir. Fakat tüm bu açıklamalara rağmen Kahire'deki Bağlantısızlar konferansında kabul edilen tebliğin Kıbrıs'a ait kısmı, Hindistan tarafından kaleme alınmıştır. Buna göre Rum Delegasyonu BM'de Kahire'deki Tarafsızlar Konferansı'nda Kıbrıs meselesi hakkında kabul edilmiş metnin benzerini karar tasarısı olarak hazırlamış ve buna Hindistan'ın "co-sponsor" olacağını duyurmuştur. Türkiye'ye göre bu istek self-determination hükmünün aslında Kıbrıslı Rumların ENOSİS isteklerini maskelemek için kullandıkları bir taktiktir. Türkiye, her ne kadar Hindistan'ın ENOSİS'e taraf olmaması için çaba gösterip çeşitli sözler almışsa da Hindistan'ın nihai kararında bir değişiklik olmamıștır. Türkiye'nin Başbakan Shastri nezdinde aldığ cevaplara rağmen, Hindistan'ın tutumunda yaşanan bu değişikliğin nedeni, Kıbrıs meselesinin halli için kabul edilecek yöntemin Keşmir meselesi için Hindistan aleyhinde bir karara dönmesi endişesidir. Kıbrıs ve Keşmir konularında benzerlik kuran Hindistan, Keşmir meselesi sebebiyle Türkiye'nin tezlerine karşı Rumları desteklemiştir. Aynı zamanda Hindistan'ın uygulamaların tutarsılılı̆ındaki diğer neden ise Türkiye'nin Keşmir meselesinde 'dost Pakistan'ı desteklemesidir. "Hindistan'ın Kıbrıs Meselesindeki Tutumuna Dair" hazırlanan rapora göre "Hindistan'ın Kıbrıs'ın bağımsız statüsünü federasyon sistemi içinde devam ettirmesini isteyen Türkiye'nin görüşünü desteklemesi için başka bir sebep görülmemektedir."

${ }^{35}$ Kıbrıs Meselesi konusunda Türkiye, Rumlara karşı 1965 öncesinde destek sağlamak üzere hareket etmişse de bu desteğin sağlanamadığı görülmüştür. Türkiye'nin 1960'lı yıllar itibariyle en önemli dış politika maddesi olan Kıbrıs, dış politikanın Keşmir konusunda Pakistan'ı desteklemesi sebebiyle Hindistan'dan istediği yardımı almasının önüne geçmiştir.

Türkiye'nin dış politikası açısından Keşmir meselesine bakışını belirleyen diğer bir olgu ise tarihsel Türk-Hint Müslümanları (Pakistan, Bangladeş ve Hindistan'da yer alan Müslümanlar) ilişkileri ile Türkiye'nin NATO ile olan ittifakıdır. Pakistan'ın tarih boyunca "bağımsız

\footnotetext{
${ }^{34}$ İsmail Akbaş, Geçmişten Geleceğe Türkiye - Pakistan İlişkileri, Zeus Kitabevi, İzmir 2013, s. 131.

${ }^{35}$ BCA, Fon Kodu: 30.1.0.0 / 64 -394 - 28, Hindistan'ın Kibrıs Meselesindeki Tutumuna Dair Rapor, 1964.
} 
Müslüman imparatorluk olarak Türkiye'ye gurur ve sevgi” ile bakması, ilişkileri Fatih Sultan Mehmet devri ile başlatması, Pakistan'ın Türkiye ve Türklere yönelik karşılıksız sevgi ve ihtiramını göstermektedir. ${ }^{36}$ Türkiye'nin Kurtuluş Savaşı süresince Hint Müslümanları, Hilafete destek olmak üzere maddi ve siyasi her türlü yardımı gerçekleştirmişlerdir. ${ }^{37}$ Tüm bu gelişmeler 1şığında ve elbette II. Dünya Savaşı sonrasında SSCB karşı kurulan ittifak dalgası içerisinde Türkiye ve Pakistan'ın birlikte yer alması, Keşmir konusunda Türkiye'nin Pakistan'ın tezine yakın durmasını sağlamıştır. Pakistan'ın Türkiye'nin de içerisinde yer aldığı Bağdat Paktı'na ve daha sonra CENTO'ya üye olması, Türkiye'nin Keşmir meselesine ittifak bloku açısından bakmasına ve desteklemesine neden olmuştur. Zira bu dönemde ABD için 'Komünist Çin' tehlikesi oldukça önemlidir. Hindistan ise Çin'i bölgede dengeleyen önemli bir ülke konumundaydı. Bu sebeple $\mathrm{ABD}$, tıpkı Kıbrıs meselesinde olduğu gibi Keşmir meselesinde de konuyu hakkaniyetli bir şekilde ele almak yerine pragmatik bir şekilde değerlendirme yoluna gitmiştir. Hint yarımadasının güvenliğini yalnızca Pakistan'a münhasır kılmayan ABD, Hindistan'ı da en az Pakistan kadar önemsemiştir. ${ }^{38}$

Türkiye ise ABD'nin görüşü doğrultusunda benzer bir biçimde, konuyu SSCB ve Çin endişesi açısından değerlendirmiştir. Türkiye'nin bu dönemde Keşmir konusundaki ilk endişesinin SSCB ve Çin olduğu şu şekilde ifade edilmiştir: "Rusya ve Çin ile Kuzey'den hemhudut olan Hint Yarımadasının her an bir Komünist tecavüzü hattâ slzması tehlikesi ile karşı karşılya bulunması ihtimali dış siyasetimizin kaygılarından biri olmakta devam edegelmiştir. " Türkiye ilginç bir biçimde bu dönemde Pakistan'ın Keşmir meselesindeki “haklı talep ve iddialarını desteklemek"te fakat "problemin barışcı ve hakkaniyete dayanan yollarla iki tarafı mümkün olduğu kadar tatmin edici şekilde halledilmesini” istemektedir. ${ }^{39}$ Türk dış politikası, 1960'lı yıllar itibariyle tarafı olduğu NATO ittifakının bir üyesi olarak, Batı'nın endişeleri doğrultusunda Keşmir meselesini değerlendirmiştir. Fakat tüm uluslararası gelişmelere rağmen Türkiye'nin savaşın dozajının $\operatorname{arttığ~} 1$ dönemlerde ise tarihsel ilişkilerin gereği olarak Pakistan'ın yanında yer aldığı görülmüştür.

Bu çerçevede Pakistan'ın Türkiye'den en büyük beklentisi, Keşmir konusundaki tezine destek vermesi olmuştur. 1965 Savaşı'ndan bir yıl önce Türkiye'ye gelerek temaslarda bulunan Pakistan Cumhurbaşkanı Muhammed Eyüp Han ${ }^{40}$, 1 Eylül 1965'te Hindistan'la savaşın ilerlediği bir dönemde mevkidașı Cemal Gürsel'e bir mektup göndererek Pakistan'ın ve Keşmirlilerin Hindistan saldırıları karşısında içerisinde bulundukları durumu belirtmiştir. Mektubun sonunda ise Eyüp Han'ın “Bu zor anda Keşmir halkının, Türk milletinin destek ve anlaylşına güvenebileceklerinden şüphem yoktur. ...Bu müşül anlarda Türk Milletinin anlaylş ve sempatisinin milletimiz ve memleketlerimizi birbirine rabdeden bağlart daha da kuvvetlendireceğine eminim" diyerek Türkiye'nin koşulsuz destek verdiğinden emin olduğunu ifade etmiştir. ${ }^{41}$

1 Eylül tarihinde yazılan mektuptan beş gün sonra başlayan yoğun çatışmada Türkiye'nin tutumu ise Eyüp Han'ın beklentisine uygun bir biçimde cereyan etmiştir. Pakistan Başbakanı Zülfikar Ali Butto Hindistan saldırısı karşısında yaptı̆̆ CENTO’yu harekete geçireceğini söylemiş ve üye ülkelerden silah yardımı istemiştir. Örgüt

\footnotetext{
${ }^{36}$ Bugünkü Pakistan Cumhurbaşkanı Muhammed Eyüp Han'in Türkiye'yi Ziyareti Münasebetiyle (3 Temmuz 19645 Temmuz 1964), Güzel İstanbul Matbaası, Ankara 1964, s. 12.

${ }^{37}$ Akbaş, age, s. 184-185.

${ }^{38}$ BCA, Fon Kodu: 30.1.0.0 / 23 - 131 - 12, Keşmir olayları ve Pakistan-Hindistan silahlı çatışmasıyla ilgili rapor, 03.09.1965.

${ }^{39}$ BCA, 30-1-0-0 / 64-395-12, Kutch bataklığı olayları, 24.05.1965.

${ }^{40}$ Pakistan Cumhurbaşkanı Muhammed Eyüp Han'ın Türkiye'yi Ziyareti, 1964.

${ }^{41}$ BCA, Fon Kodu: 30.1.0.0 / 64 -396 - 10, Muhammed Eyüb Han'ın Cemal Gürsel'e mektubu, 01.09.1965.
} 
üyeleri olan İran ve Türkiye, 8-10 Eylül tarihlerinde konu ile ilgili olarak dışişleri bakanları nezdinde Ankara'da görüşmüş ve bir bildiri yayınlamışlardır. Bildiriye göre, Hindistan suçlanırken, BM barış gücüne asker gönderebileceklerini ve Pakistan'1 desteklemeye hazır olduklarını bildirmişlerdir. Tüm bu gelişmelere karşı Türkiye, Pakistan'ın istediği 24 savaş uçağını ABD yardımının bir parçası olarak NATO tarafından verilen silahların verilemeyeceği gerekçesiyle verememiştir. ${ }^{42}$ Türkiye'nin kısa bir süre önce Johnson Mektubu ile Kıbrıs konusu dâhilinde NATO silahlarını kullanamayacağı sebebiyle uyarılması, bu kararın verilmesinde önemli bir etken olmuştur. Fakat tüm bunlara rağmen Türkiye, yine de 5 milyon değerinde askeri malzeme ve silahı Pakistan'a göndermiştir. ${ }^{43}$

Türkiye'nin Pakistan konusunda tarihsel dostluğu ile dâhil olduğu Batı ittifakı sebebiyle yaşadığı gelgitli durum, Türkiye'nin resmi olarak Keşmir konusunda kesin taraf olmasını etkilemiştir, fakat bu durum 1965 Savaşı sürecinde Türkiye'nin Pakistan'a yardım etmesini engellememiştir. 3 Eylül 1965 tarihinde yapılan bir değerlendirmede ise Türkiye'nin Keşmir konusundaki değişken politikası şu şekilde ifade edilmiştir; "Hükûmetimizin Keşmir meselesile ilgili görüşlerini temsil eden beyanlar yaplldıları şartlara göre bazı farklar arzetmekle beraber daima Pakistan' 'n durumunu destekler mahiyettedir." 44

\section{Sonuç}

1947 yılında Hindistan ve Pakistan'ın İngiltere'den bağımsızlıklarını kazanmaları sonrasında İngiltere, özel bir statüye sahip olan racalıkların her iki devletten birine dâhil olmalarına ya da bağımsız olarak kalmalarını racaların tercihine bırakmıştır. Bu racalıklardan bir tanesi olan Keşmir; nüfusu, dini yapısı, zengin ve geniş coğrafyasıyla Hindistan ve Pakistan arasında yer alan oldukça önemli bir konumdaydı. Stratejik konumu ve zengin coğrafyasıyla Keşmir, halkın büyük çoğunluğunun Müslüman olmasına rağmen hukuka aykırı olarak ve bir oldubittiyle Hindistan'a bağlanmış ve kısa süre içerisinde de Hindistan ve Pakistan arasında savaşa yol açmıştır. Birinci Hindistan-Pakistan Savaşı sonrasında iki devlet arasında süren çatışma hali ve Hindistan'ın Keşmirlilerin plebisit gibi resmi olarak kabul edilmiş olan hukuki haklarını yok sayması, Pakistan-Hindistan mücadelesini 1960'l yıllara kadar devam ettirmiştir. Soğuk Savaş'ın iki kutuplu yapısının her iki tarafa sirayet etmesi ise Keşmir'in çözümsüzlüğünün sürmesine neden olmuştur. Özellikle Hindistan'ın ABD'nin Asya için temel endişe kaynağı haline gelen 'Komünist Çin'i dengeleyen önemli bir devlet olması, Pakistan yerine Hindistan'ın tercih edilebilirliğini gündeme getirmiş, bu durum ise Keşmir konusunda Hindistan'ın tutumunu güçlendirmiştir. 1965 yılında geldiğimizde Hindistan'ın uluslararası sistemden kaynaklanan yapıyı Keşmirliler üzerinde tahakküm kurmak üzere değerlendirmesi, ikinci kez Hindistan-Pakistan arasında savaş yaşanmasına neden olmuştur.

Türkiye'nin dış politikası açısından Keşmir meselesi, 1947 yılı için öncelikli bir mesele olarak görülmemiştir. 1945 yılında SSCB'den kaynaklı olarak yaşadığı güvenlik tehlikesi, Türkiye'nin Keşmir meselesine büyük bir oranda dâhil olmasını etkilemiştir. Türkiye, yaşadığı güvenlik endişesi sebebiyle 1947 yılında yaşanan Hindistan-Pakistan Savaşı sırasında Keşmir ve tarihsel dostluk bağlarına sahip olduğu Pakistan'la irtibat sağlayamamıştır. 1960'lı yıllara geldiğimizde ise bu kez Türkiye'nin bloklar arasında yaşanan detant/yumuşama dönemi sebebiyle, kendi sınırları dışındaki meselelerle de ilgilendiği görülmüştür. Keşmir ise bu konuda önemli noktalardan birisi olmuştur. Türkiye, yaşanan detant nedeniyle -Kıbrıs konusu başta olmak üzere- Batı'dan nispeten bağımsız şekilde dış politikasını sürdürse de SSCB tehlikesinin hali hazırda devam etmesi, dış politikanın Keşmir ve Pakistan konusunda tamamen

\footnotetext{
${ }^{42}$ Sander, age, s. 380-381.

${ }^{43}$ Armaoğlu, age, s. 664.

${ }^{44}$ BCA, Fon Kodu: 30.1.0.0 / 23 - 131 - 12, Keşmir olayları ve Pakistan-Hindistan silahlı çatışması, 03.09.1965.
} 
bağımsız olmasını etkilemiştir. Yaşanılan uluslararası gelişmeler ve tarihsel Pakistan dostluğu, gerek 1965 öncesinde gerekse sonrasında Türk dış politikasının Keşmir konusunda gelgitli bir süreç yaşamasına neden olmuştur. Özellikle Türkiye, ABD ile yaşadığı 1962 Füze Krizi, 1964 Johnson Mektubu gibi sorunlar sebebiyle daha bağımsız bir dış politika yürütmek istemekle birlikte, dâhil olduğu ittifak yapısı, Türkiye'nin tamamen ABD aleyhinde bir politika izlemesinin önüne geçmiştir. Bu durumun Türkiye'nin Keşmir olaylarına bakışını engellediği görülmüştür.

Türkiye, tarihsel süreçte dış politika teamüllerine aykırı olarak 'dost' olarak nitelendirdiği Pakistan'ı kamuoyu ve devlet nezdinde desteklerken bazı dönemlerde ise ABD'nin Hindistan alt kıtasında yürüttüğü küresel siyasetin bir parçası olarak hareket etmiştir. Bu durumun sonucu olarak Keşmir ile ilgili hazırlanan raporlarda bu duruma tesadüf edilmektedir. Bazı raporlarda Hindistan-Pakistan çatışmasına tarafsız bir şekilde bakılırken bazı raporlarda ise tenakuz oluşturacak surette çeşitli ifadelere yer verildiği gözlemlenmiştir. Türk dış politikasının Keşmir konusunda, NATO'nun çıkarları ile kendi kamuoyunun tercihleri arasında kaldığg görülmüştür. Savaş veya çatışmanın olmadığı durumlarda Türkiye, NATO'nun görüşüne yakın bir surette Keşmir meselesinin Çin, SSCB gibi devletlerin Hint alt kıtasına yayılmasına müsaade etmeyecek şekilde çözülmesini isterken savaş döneminde ise diş politika söylemlerinin değiştiği görülmüş̧ür. Kamuoyu hassasiyetinin arttığ 1 bu dönemlerde Türkiye, Keşmir konusunda Pakistan'dan yana tavır takınmıştır. Bu doğrultuda Türkiye, 1965 Savaşı başladıktan sonra Keşmir meselesinde, Pakistan'ın yanında yer almıştır. Türkiye, savaş başladıktan hemen sonra sahip olduğu kaynakları Pakistan lehine kullanmak istemiş, bu doğrultuda CENTO'yu harekete geçirmeye çalışmış ve Pakistan için CENTO'dan yardım istemiştir. Türkiye her ne kadar Johnson Mektubu nedeniyle 1965 Savaşı sırasında Pakistan'ın istediği uçakları gönderemese de 5 milyon değerinde askeri malzeme ve silah göndererek Pakistan halkının yanında olmuştur.

\section{Kaynakça}

\section{Arşivleri Belgeleri}

Devlet Arşivleri Başkanlığı Cumhuriyet Arşivi (BCA)

BCA: 30.1.0.0 / 64 -394 -28, Hindistan'1n Kibris Meselesindeki Tutumuna Dair Rapor, 1964.

BCA: 30.1.0.0 / 64-395-12, Pakistan ve Hindistan arasında hudut ihtilafları ve Kutch bataklığı olayları hakkında rapor, 24.05.1965.

BCA: 30.1.0.0 / 64 -396 - 10, Dışişleri Bakanı Hasan Işık'ın Keşmir meselesine ait beyanatı, 06.09.1965.

BCA: 30.1.0.0 / 23 - 131 - 12, Keşmir olayları ve Pakistan-Hindistan silahlı çatışmasıyla ilgili rapor, 03.09.1965.

BCA: 30.1.0.0 / 64 -396 - 10, Muhammed Eyüb Han'ın Cemal Gürsel'e mektubu, 01.09.1965.

\section{Kitap ve Makaleler}

ALTUĞ, Yılmaz, Başlangıcından Günümüze Keşmir Meselesi, İrfan Yayınevi, 2002.

AKBAŞ, İsmail, Geçmişten Geleceğe Türkiye - Pakistan İlişsileri, Zeus Kitabevi, İzmir, 2013.

ARI, Tayyar, Global Politika ve Güney Asya Keşmir Sorunu ve Nükleer Yarış, Alfa Basım Yayım, 2. Bask1, 2000.

ARMAOĞLU, Fahir, 20. Yüzyll Siyasi Tarihi 1914-1995, Alkım Yayınevi, 14. Bask1. 
Bugünkü Pakistan Cumhurbaşkanı Muhammed Eyüp Han'ın Türkiye’yi Ziyareti Münasebetiyle (3 Temmuz 1964-5 Temmuz 1964), Güzel İstanbul Matbaas1, Ankara, 1964.

ÇEBİ, Emrin, Keşmir Raporu: Tarihî Süreç ve Bölgeye Dair Çözüm Önerileri, Araştırma 75, İNSAMER, Ağustos 2018.

ÇETINKAYA, Selma Göktürk, "Bağdat Paktı'nın Kuruluş Sürecinde Türkiye'nin Ortadoğu ve Batı ile İliş̧kileri", Vakanüvis Uluslararası Tarih Araştırmaları Dergisi, C.1, S. Ortadoğu Özel Sayıs1, 2016, s.1-29.

DİNÇER, Mustafa, "Keşmir: Himalaya Eteklerinde Bağımsızlık Mücadelesi”, Dünya Çatı̧ma Bölgeleri, Ed., Kemal İnat, Burhanettin Duran, Muhittin Ataman, s. 659-671.

PAKİSTAN ANKARA SEFARETI BASIN ATAŞELIĞİ, Keşmir Meselesi, La Turquie Modern Basımevi, İstanbul, 1952.

ÖZCAN, Azmi, “Dünden Bugüne Keşmir ve Keşmir Meselesi”, Keşmir Dosyası, Yayına Hzr. Halil Toker, TATAV Yayınları, İstanbul, 2003, s. 31-38.

RIZVI, Saıyıd Athar Abbas, "Keşmir", Türkiye Diyanet Vakfı İslam Ansiklopedisi, Cilt: 25, Ankara, 2002, s. 325-327.

SANDER, Oral, Siyasi Tarih Birinci Dünya Savaşının Sonundan 1980'e Kadar, İmge Kitabevi, Ankara, 1989.

TOKER, Halil, “Cunagard ve Haydarabad Bağlamında Keşmir'in Hindistan'a İlhakı Üzerine Bir Değerlendirme", Keşmir Dosyası, Yay. Hzr., Halil Toker, TATAV Yayınları, İstanbul, 2003, s. 67-88.

Volume 11

TOKER, Halil, Sebepleri ve Sonuçları İle Keşmir Meselesini Kavramak, Demavend Yayınları, 2019 İstanbul, 2017. 